\title{
Embryonic Tumor with Abundant Neuroepithelium and True Rosettes (ETANTR): Case Report and Literature Review
}

\section{Tumor embrionário com abundante neuroepitélio $e$ verdadeiras rosetas (ETANTR): relato de caso e revisão da literatura}

\author{
Cleciton Braga Tavares ${ }^{1}$ Francisca das Chagas Sheyla Almeida Gomes-Braga ${ }^{2}$ Emerson Brandão Sousa ${ }^{1}$ \\ Camilla Aniele Areia Ferreira ${ }^{3}$ José Nazareno Pearce de Oliveira Brito ${ }^{1}$
}

${ }^{1}$ Department Neurosurgery, Hospital São Marcos, Teresina, Piauí

2 Hospital Universitário, Universidade Federal do Piauí, Teresina, Piauí

3 Universidade Federal do Piauí, Teresina, Piauí

Arq Bras Neurocir 2017;36:247-250.
Address for correspondence Cleciton Tavares, MSc, Universidade

Federal do Piauí, Teresina, PI, Brazil

(e-mail: bragatavares@yahoo.com.br).

\begin{abstract}
Keywords

- primitive neuroectodermal tumors

- ependymoblastoma

- neuroblastoma
\end{abstract}

\section{Resumo}

The embryonal tumor with abundant neuropil and true rosettes (ETANTR) is an extremely rare variant of the primitive neuroectodermal tumor (PNET). About 80 cases have been reported since its first description in the literature, in 2000. The ETANTR occurs in very young patients, especially children under 6 years of age. It is found mainly in the cerebral cortex. Headache, focal neurological signs, seizures, increased head circumference and psychomotor developmental delay are the most frequent symptoms of ETANTR. Histologically, it displays the features of an ependymoblastoma and a neuroblastoma, showing areas of neuroepithelium fibrillar rosettes with ependymoblastic zones and interposed undifferentiated neuroepithelial cells. The ETANTR is distinguishable from other embryonal tumors due to the abundance of neuroepithelium. Genetic studies have demonstrated the presence of polysomy of chromosome 2 and chromosome 19q13.42 amplification. This is an extremely aggressive tumor with a mean survival ranging from 9 to 48 months. We present the first report in Brazil, published in indexed literature, of an ETANTR case involving a young child.

O tumor embrionário com neurópilo abundante e rosetas verdadeiras (TENARV) é uma variante muito rara do tumor neuroectodérmico primitivo (TNEP), com cerca de 80 casos publicados desde a sua primeira descrição na literatura, em 2000. O TENARV ocorre em pacientes muito jovens, especialmente crianças abaixo de 6 anos de idade, atingindo principalmente o córtex cerebral. Cefaleia, sinais focais, crise convulsiva, aumento do perímetro cefálico e atraso do desenvolvimento psicomotor são os sintomas mais frequentes da TENARV. Histologicamente, este tipo de tumor apresenta received

July 17, 2017

accepted

September 14, 2017

published online

October 23, 2017
DOI https://doi.org/

10.1055/s-0037-1607358. ISSN 0103-5355.
Copyright $\odot 2017$ by Thieme Revinter

Publicações Ltda, Rio de Janeiro, Brazil
License terms

(c) (i) $\ominus$ (\$) 


\begin{tabular}{|c|c|}
\hline & $\begin{array}{l}\text { as características combinadas de um ependimoblastoma e um neuroblastoma, de- } \\
\text { monstrando áreas de neuroepitélio fibrilar com rosetas ependimoblásticas de permeio }\end{array}$ \\
\hline $\begin{array}{l}\text { Palavras-chave } \\
\text { - tumores } \\
\text { neuroectodérmicos } \\
\text { primitivos } \\
\text { - ependimoblastoma } \\
\text { - } \\
\text { neuroblastoma }\end{array}$ & $\begin{array}{l}\text { e zonas de células neuroepiteliais indiferenciadas. O TENARV é distinguível de outros } \\
\text { tumores embrionários pela abundância de neuroepitélio. Estudos genéticos demons- } \\
\text { tram a presença de polissomia do cromossomo } 2 \text { e amplificação do cromossomo } \\
19 q 13.42 \text {. Trata-se de um tumor extremamente agressivo, com sobrevida média entre } \\
9 \text { e } 48 \text { meses. Apresentamos o primeiro relato brasileiro, publicado em literatura } \\
\text { indexada, de um caso de TENARV acometendo uma criança jovem. }\end{array}$ \\
\hline
\end{tabular}

\section{Introduction}

According to the World Health Organization (WHO) classification, there are three types of primitive embryonal tumors of the central nervous system: medulloblastoma, atypical teratoid/rhabdoid tumor and primitive neuroectodermal tumor (PNET). The latter has five subtypes: primitive neuroectodermal tumor not otherwise specified (PNET-NOS), neuroblastoma, ependymoblastoma, medulloepithelioma and ganglioneuroblastoma. ${ }^{1,2}$

The embryonal tumor with abundant neuropil and true rosettes (ETANTR) is an extremely rare variant of the PNET, with characteristics in common with both the neuroblastoma and the ependymoblastoma. There are $\sim 80$ published cases since its first description in the literature, in 2000, by Eberhart et al. ${ }^{2,3}$

The ETANTR occurs in very young patients, especially in children under 6 years of age, with a slight predominance in females, and it is found in the cerebellum, brainstem, pineal gland and especially the in the cerebral cortex, with greater predilection for the frontal and parietal lobes. ${ }^{2,4,5}$ We present herein the first report in Brazil, published in indexed literature, of an ETANTR case involving a young child.

\section{Case Report}

A 3-year-old male patient has reported headache with progressive intensity, disorientation and partial motor seizures during 20 days of hospitalization. About 18 hours after the patient's admission to the emergency neurosurgery service of a hospital in Brasília, Brazil, the symptoms evolved with a sudden decrease in the level of consciousness, anisocoria and right decerebration.

A brain computed tomography (CT) scan showed the presence of a heterogeneous lesion, with cystic areas and inner calcification, located in the right frontal lobe and

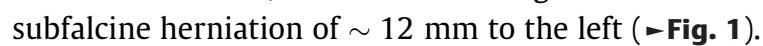

The patient underwent emergency decompressive craniotomy with complete excision of the tumor and the overlying dura. Macroscopically, it presented as an injury that was fibroelastic, slightly hemorrhagic, had well-defined borders in most of its length, invading the dura but not involving the skull. A duraplasty was performed with autologous pericranium.

The histopathology examination showed a primitive supratentorial neuroectodermal tumor with areas of ependymoblastoma and areas of abundant neuropil, presence of necrosis, atypia, pleomorphism cells as well as mitoses (grade IV as per the WHO classification of tumors of the central nervous system) (-Fig. 2). The immunohistochemistry showed positivity for vimentin (VIM) and negativity for pancytokeratin (PANCK), glial fibrillary acidic protein (GFAP), epithelial membrane antigen (EMA), S-100 protein, neuron-specific enolase (NSE) and p-53 protein. The Ki-67 protein was present in $30-40 \%$ of the cells ( - Fig. 3 and - Table 1 ). Lesions with these features have been considered as ETANTRs.

The patient remained hospitalized for 2 days in the intensive care unit (ICU), intubated, sedated and on mechanical ventilation. On the 10th day postoperatively, he was discharged from the hospital, conscious and oriented, with no motor or sensory deficit and without seizures.

The patient has been followed-up at an outpatient chemotherapy setting and, currently, there are no complaints.

\section{Discussion}

In this report, the patient presented with severe and rapidly progressive clinical signs, which is consistent with the literature. Headache, focal signs, seizures, increased head circumference and psychomotor developmental delay are the most frequent symptoms of ETANTR. ${ }^{6}$ Imaging exams show heterogeneous injuries unenhanced and contrast-media enhanced. The ETANTR may show calcifications or cysts, as seen in our patient. ${ }^{5,6}$ Its main differential diagnoses are desmoplastic infantile ganglioma, supratentorial ependymomas and PNETs. ${ }^{2}$

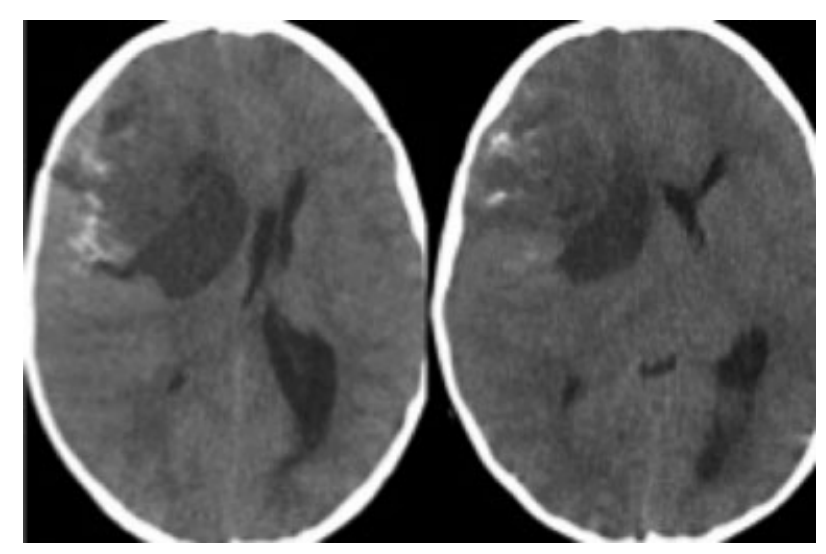

Fig. 1 Skull computed tomography without contrast shows heterogeneous right frontal lesion and subfalcine herniation. Source: Radiology Department of the Hospital de Base do Distrito Federal - Brasília - Brazil. 


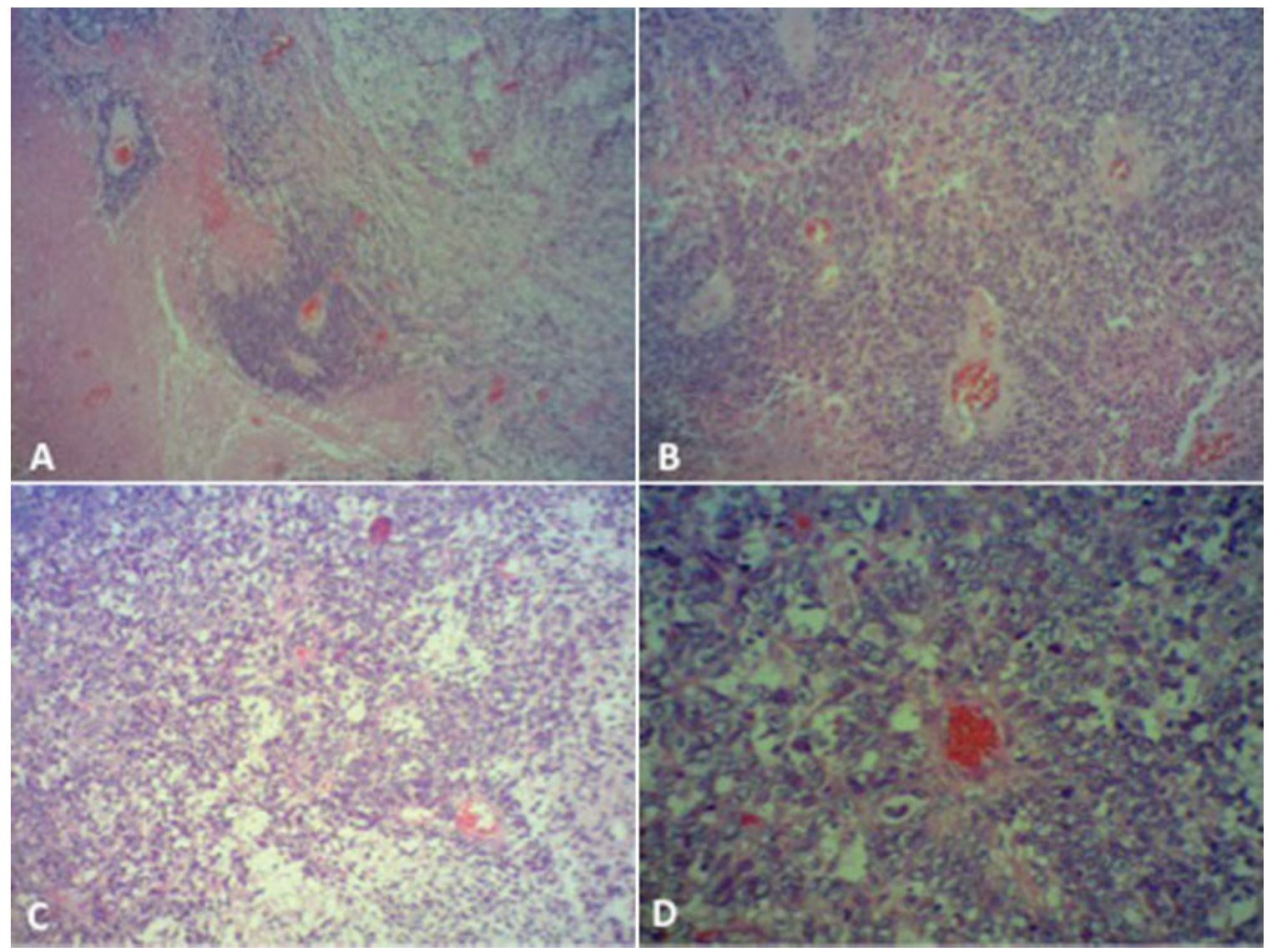

Fig. 2 Histopathology, hematoxylin-eosin coloration. (A) Embryonic tumor with neuropilic areas and ependymoblastic rosettes, (B) Perivascular rosettes, (C) Undifferentiated neuroepithelial areas and (D) Pseudo-rosette with accentuated pleomorphism. Source: Pathology Department of the Hospital de Base do Distrito Federal - Brasília - Brazil.

Histologically, it displays the characteristics of both an ependymoblastoma and a neuroblastoma, showing areas of neuroepithelium fibrillar with ependymoblastic rosettes interposed and undifferentiated neuroepithelial cells. The ETANTR is distinguishable from other embryonal tumors due to the abundance of neuroepithelium, and it often has more ependymoblastic rosettes than the ependymoblastomas themselves. ${ }^{2}$

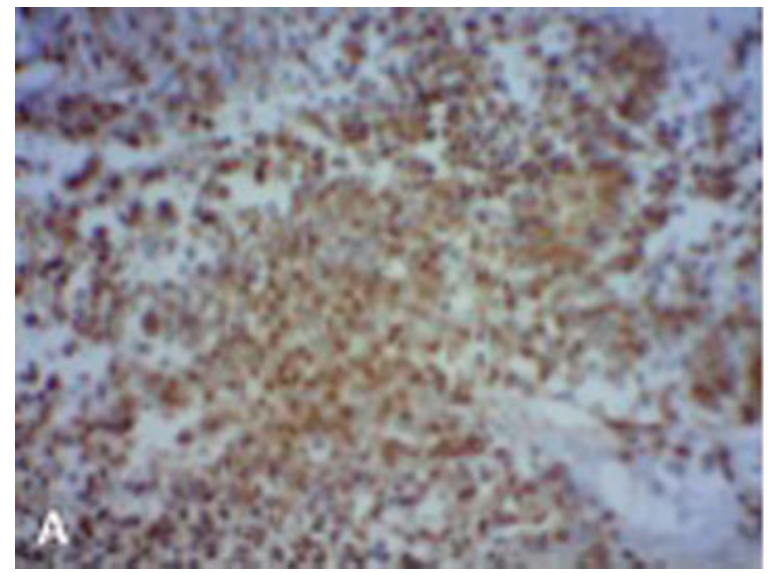

The immunohistochemistry normally shows positivity for synaptophysin in the neuroepithelial cells, microtubule associated protein 2 (MAP2) in the tumor cells and for VIM, p53 protein, Nestin and $\beta$-catenin in the ependymoblastic rosettes. There was no evidence of EMA or cluster of differentiation 99 (CD99) in any of the components. ${ }^{4,7}$

Genetic studies have demonstrated the presence of polysomy of chromosome 2 , and the amplification of chromosome

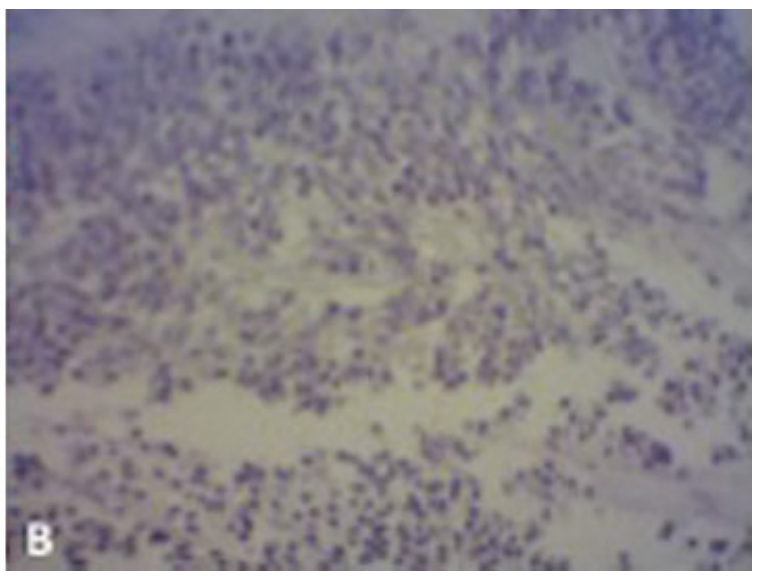

Fig. 3 Immunohistochemistry. (A) positive VIMENTINE marker and (B) Ki-67 positive in 30-40\%. Source: Pathology Department of the Hospital de Base do Distrito Federal - Brasília - Brazil. 
Table 1 Results of immunohistochemical markers

\begin{tabular}{|l|l|}
\hline Markers & Results \\
\hline GFAP & negative \\
\hline EMA & negative \\
\hline S-100 & negative \\
\hline VIM & positive \\
\hline PANCK & negative \\
\hline MELAN-A & negative \\
\hline CEA & negative \\
\hline Ki-67 & $30-40 \%$ \\
\hline
\end{tabular}

Abbreviations: CEA, carcinoembryonic antigen; EMA, epithelial membrane antigen; GFAP, glial fibrillary acidic protein; Ki-67, Ki-67 protein; Melan-A, melanoma antigen; PANCK, pancytokeratin; S-100, S-100 protein; VIM, vimentin.

Source: Service of Pathology of Hospital de Base do Distrito Federal, Brasília, Brazil.

19q13.42. This last change, in special, can also be found in ependymoblastomas and medulloepytheliomas. $2,3,8,9$

In most of the case reports, extensive surgical resections of the lesions were performed, followed by a high dose of chemotherapy and, when possible, craniospinal radiotherapy. Similarly to PNETs, the ETANTRs seem to be less sensitive to chemotherapy. ${ }^{1,2}$

The ETANTR is an extremely aggressive tumor, with a mean survival between 9 and 48 months. Better prognosis is usually found in older children, perhaps because they can make use of adjuvant radiotherapy. ${ }^{2,5}$

\section{References}

1 Ferri Niguez B, Martínez-Lage JF, Almagro MJ, et al. Embryonal tumor with abundant neuropil and true rosettes (ETANTR): a new distinctive variety of pediatric PNET: a case-based update. Childs Nerv Syst 2010;26(08):1003-1008

2 Manjila S, Ray A, Hu Y, Cai DX, Cohen ML, Cohen AR. Embryonal tumors with abundant neuropil and true rosettes: 2 illustrative cases and a review of the literature. Neurosurg Focus 2011;30(01):E2

3 Ryzhova MV, Zheludkova OG, Ozerov SS, et al. Kushel' IuV, Korshunov AE. A new entity in WHO classification of tumors of the central nervous system-embryonic tumor with abundant neuropil and true rosettes: case report and review of literature. Vopr Neirokhir 2011;4:25-33

4 Wang Y, Chu SG, Xiong J, Cheng HX, Chen H, Yao XH. Embryonal tumor with abundant neuropil and true rosettes (ETANTR) with a focal amplification at chromosome 19q13.42 locus: further evidence of two new instances in China. Neuropathology 2011;31 (06):639-647

5 Gessi M, Giangaspero F, Lauriola L, et al. Embryonal tumors with abundant neuropil and true rosettes: a distinctive CNS primitive neuroectodermal tumor. Am J Surg Pathol 2009;33(02):211-217

6 Dunham C, Sugo E, Tobias V, Wills E, Perry A. Embryonal tumor with abundant neuropil and true rosettes (ETANTR): report of a case with prominent neurocytic differentiation. J Neurooncol 2007;84(01):91-98

7 Al-Hussaini M, Abuirmeileh N, Swaidan M, et al. Embryonal tumor with abundant neuropil and true rosettes: a report of three cases of a rare tumor, with an unusual case showing rhabdomyoblastic and melanocytic differentiation. Neuropathology 2011;31(06):620-625

8 Nobusawa S, Yokoo H, Hirato J, et al. Analysis of chromosome 19q13.42 amplification in embryonal brain tumors with ependymoblastic multilayered rosettes. Brain Pathol 2012;22(05):689-697

9 Korshunov A, Remke M, Gessi M, et al. Focal genomic amplification at 19q13.42 comprises a powerful diagnostic marker for embryonal tumors with ependymoblastic rosettes. Acta Neuropathol 2010;120(02):253-260 